\title{
The healthcare professional and the Bolam test
}

\author{
J. Warren Jones 1
}

\begin{abstract}
This article will cover the history of the tort of negligence and how the judgement in the case of Donoghue $v$ Stevenson enabled the courts to 'develop the law' to allow the concept of a 'duty of care' to develop which was extended to include healthcare professionals. The Bolam test is then described and how it has come to play such a prominent role in assisting the courts to assess if an appropriate standard has been achieved in medical negligence litigation. Attempts by the courts to move away from Bolam are discussed and the difficulties encountered because of the reluctance of the appellate courts to approve such decisions. Finally the recent House of Lords decision in Bolitho $v$ City and Hackney Health Authority is examined and the implications this may have on the Bolam test.
\end{abstract}

\begin{abstract}
The appropriate standard of care and whether a defendant has met that standard, are two of the crucial issues in any medical negligence action. The court has to decide if the defendant has exercised sufficient care. Under the tort of negligence, the test for breach of duty is whether or not the defendant's conduct was reasonable taking all the circumstances into account. Expert medical opinion is obviously important in assisting the courts to decide whether or not the defendant has exercised an appropriate level of skill under the circumstances of the case, but it is the courts and not expert medical opinion that should decide if the defendant has achieved that standard.
\end{abstract}

\section{History of the tort of negligence}

Negligence was not recognised as a separate tort until 1932. Its development can be traced to the House of Lords ruling in the case of Donoghue $v$ Stevenson. ${ }^{1}$ Despite its relatively recent beginning, Millner has stated that most tort actions in recent times are for negligence. ${ }^{2}$ Donoghue $v$ Stevenson was concerned with what was claimed to be the decomposed remnants of a snail in a bottle of ginger beer. The principle could have been kept narrow and held to apply to

${ }^{1}$ Consultant in Orthodontics, Warrington Hospital NHS Trust, Lovely Lane, Warrington, Cheshire WA5 1QG

REFEREED PAPER

Received 11.03.99; accepted 24.08.99

(c) British Dental Journal 2000; 188: 237-240 the manufacturers of food or drink who would have had a duty of care to prevent consumers suffering damage from foreign bodies. However, while the courts were obviously aware of the 'floodgates argument' and the effect this could have, they decided that the principle in Donoghue $v$ Stevenson would apply wherever it was considered a duty of care was owed in specific circumstances. It is as an extension of the principle in Donoghue $v$ Stevenson that healthcare professionals have been deemed to owe a duty of care to their patients.

It has been argued that some important points emerge from Donoghue $v$ Stevenson. In order to establish negligence, a plaintiff (the person bringing the action) must prove:

- The defendant (the person defending the action) owed him a duty of care

- There was breach of that duty

In brief

- Negligence was not recognised as a separate tort (wrong) until 1932

- Case law has allowed the development of a duty of care to include healthcare professionals

- The Bolam test which was formulated by a high court judge in 1957 has guided the courts as to the standard of care in medical negligence cases.
- Damage flowing from the breach, which is not too remote, ie causation.

Historically, there has been reluctance on the part of the judiciary to find doctors guilty of negligence. This may be because lawyers and doctors belong to two of the oldest professions. Many judges have felt that doctors needed to be protected from the threat of medical negligence. This was illustrated in 1954, in the case of Hatcher $v$ Black, where Lord Denning, a well-known supporter of the medical profession, described negligence as a 'dagger at the doctor's back.' ${ }^{3}$ The test which has become the principle by which medical negligence is assessed is known as 'The Bolam' test.

\section{The Bolam Test}

Since 1957, the Bolam test has been the benchmark by which professional negligence has been assessed. It is based on the direction to the jury of a high court judge, McNair J, in Bolam v Friern Hospital Management Committee. ${ }^{4}$

'A doctor is not guilty of negligence if he has acted in accordance with a practice accepted as proper by a responsible body of medical men skilled in that particular art. Putting it another way round, a doctor is not negligent if he is acting in accordance with such a practice, merely because there is a body of opinion that takes a contrary view.'

This statement of law has been subsequently approved by the House of Lords in a number of important test cases as the basis of liability in medical negligence cases:

- Maynard $v$ West Midlands Regional Health Authority ${ }^{6}$ (diagnosis)

- Whitehouse vordan ${ }^{7}$ (treatment)

- Sidaway v Bethlem Royal Hospital Governors ${ }^{8}$ (disclosure of information and consent).

The Bolam test has been criticised as a state-of-the-art descriptive test based on what is actually done, whereas in negligence cases generally, the test is a normative test based on what should be done. This has made it more difficult for plaintiffs to 
succeed in medical negligence cases and was commented on by the Pearson Commission who noted the difference between the success of negligence claims generally $(60 \%-$ $80 \%)$ as opposed to medical negligence claims $(30 \%-40 \%){ }^{9}$

\section{Commonly adopted working practices and negligence}

Outside the context of medical negligence the courts have had no difficulty with the concept that commonly adopted practices may be negligent. This is shown in Edward Wong Finance Company Ltd v Johnson Stokes and Masters where the Privy Council held that a particular conveyancing practice widely followed in Hong Kong was negligent despite the fact that virtually all other solicitors adopted the same practice. ${ }^{10} \mathrm{Sim}$ ilarly in Re The Herald of Free Enterprise: Appeal by Captain Lewry the Divisional Court found that the practice of failing to check that the doors had been closed was prevalent in most if not all ferries of that class. ${ }^{11}$ The Court concluded, however, that this was not evidence of the appropriate standard of care, but a failure to apply common sense in respect of elementary precautions required for the safety of the ship and that the practice was negligent.

\section{Trainees and the standard of care}

Interestingly the Courts do not make an allowance for 'trainees' when assessing liability. In 1971 the case of Nettleship $v$ Western (concerning a learner driver) showed that people who are learning a skill must exercise the same standard of care as those who are already proficient in that skill. ${ }^{12}$ A trainee's 'incompetent best' is not good enough. This may seem harsh at first sight, but on reflection is essential for public confidence. ${ }^{13}$

This principle of one standard of care regardless of experience has also been applied to the medical profession. In Jones $v$ Manchester Corporation the Court of Appeal held that inexperience was no defence when a patient died from an excessive dose of anaesthetic administered by an inexperienced doctor. ${ }^{14}$ The later case of Wilsher $v$ Essex Area Health Authority (1988) confirmed this principle; ${ }^{15}$ a junior doctor working in a special care baby unit put a catheter into the wrong blood vessel which resulted in excess oxygen and the condition of retrolental fibroplasia; and the baby subsequently became blind. Defence counsel argued that this was an easy error to make in such a small infant and as the plaintiff was a junior doctor you could not expect any more. The court rejected this argument and held that junior doctors are required to adhere to the same standard of care as those who are more senior. The concept of 'team negligence' was introduced, and it was held everyone working in the unit was expected to exercise the same professional standard, and to look to a more senior person for advice if necessary. In Wilsher, Lord Browne-Wilkinson also said that a health authority that fails to provide doctors of sufficient skill and experience could be held directly liable in negligence to the patient. This is in addition, of course, to the vicarious liability which a hospital has for the action of its employees (in this case doctors).

\section{Departure from the Bolam test}

There have been limited attempts by the courts to move away from the Bolam test but almost inevitably appellate (higher) courts have overruled their decisions.

\section{Courts choosing between different bodies of expert medical opinion:}

Apart from a limited number of cases the courts have shown themselves to be reluctant to choose between different bodies of expert medical opinion mindful of their own lack of medical knowledge unless the opinion of a doctor or group of doctors was 'Wednesbury unreasonable,' ie a view such as no reasonable doctor could have held. ${ }^{16}$ Lord Green's much quoted test, which has become known as the test for 'Wednesbury unreasonableness' is:

If a decision...is so unreasonable that no reasonable authority could ever have come to it, then the court can interfere. That, I think, is quite right; but to prove a case of that kind would require something overwhelming.'

It would thus seem that little has changed in recent years in medical negligence cases, as the guidance given by the appellate courts is, that if judges choose between different bodies of expert opinion, it must be on the basis of Wednesbury unreasonableness, a test which has proved extremely difficult to satisfy.

\section{Deviations from accepted clinical practice and advances in medical science:}

If complying with accepted clinical practice is good evidence that a doctor has acted with reasonable care, is departure from accepted practice evidence of negligence? If deviation from normal clinical practice were to be considered proof of negligence in all circumstances then clinicians could not pioneer new techniques or surgical procedures without facing the risk of a negligence action if something went wrong. In Hunter $v$ Hanley (1955) (a Scottish case which preceded the Bolam case by two years) Lord Clyde commented that this '...would be disastrous... for all inducement to progress in medical science would then be destroyed.' ${ }^{17}$

In the same case his Lordship gave guidance that there were three requirements to establish liability where deviation from normal practice is alleged.

....First it must be proved that there is a usual and normal practice; secondly it must be proved that the defendant has not adopted that practice; and thirdly (and this is of crucial importance) it must be established that the course the doctor adopted is one that no professional man of ordinary skill would have taken if he had been acting with ordinary care.'

\section{Bolam and continuing medical education}

How does the Bolam test apply to the medical profession and continuing professional education (keeping up-to-date)? In Bolam v Friern Hospital Management Committee ${ }^{18}$ McNair J stated that a doctor cannot:

'obstinately and pig-headedly carry on with some old technique if it has been proved to be contrary to what is really substantially the whole of informed medical opinion.'

In Crawford $v$ Charing Cross Hospital the 
plaintiff developed brachial palsy in an arm following a blood transfusion. ${ }^{19}$ At first the defendant was found guilty on the basis of an article published in the Lancet 6 months previously. The Court of Appeal overturned this decision, saying it would be too great a burden to expect a doctor to read every article in medical journals. The courts may be reluctant to convict on the basis of one article, but where a particular risk has been highlighted on a number of occasions it will be difficult to defend an action where a practitioner has not taken this into account. This is particularly so with the advances in recent years in information technology.

\section{Legal precedent and the Bolam test}

The House of Lords (1966) does have the power to overrule previous decisions of its own, if it appears 'right to do so', in the light of changed circumstances. ${ }^{20}$ The covering document states by clarification:

'An example of a case in which the House of Lords might think it right to depart from a precedent is where they consider that the earlier decision was influenced by the existence of conditions which no longer prevail, and that in modern conditions the law ought to be different.'

It was hoped that the House of Lords might have taken the opportunity to make radical changes to the concept of the Bolam test when they recently considered a medical negligence case, Bolitho $v$ City and Hackney Health Authority in a long awaited decision. ${ }^{21}$ The House of Lords considered two issues in this appeal case:

- Causation where there is an omission as opposed to an action

- The application of the Bolam test in medical negligence cases.

The case concerned a boy, Patrick Bolitho, who was admitted on 11 January 1984 to St Bartholomew's Hospital suffering from croup. He was subsequently discharged but re-admitted because of further breathing difficulties. Patrick experienced further breathing difficulties while in hospital and experienced a cardiac arrest. Because of a period of about 10 minutes before respira- tory and cardiac functions were re-established, Patrick subsequently died from severe brain damage. The defence accepted that there had been a breach of duty by $\mathrm{Dr} \mathrm{H}$ in not attending Patrick or ensuring that a deputy attended him on her behalf. What was under consideration was causation. Dr $\mathrm{H}$ contended that had she attended Patrick she would not have intubated him; she stated this was not necessary as for a young patient the procedure itself carries a certain degree of mortality and morbidity. The plaintiff's (patient's) expert medical witnesses contended she should have intubated him, as this would have protected his airway and thus saved his life.

The issues to be considered by the House of Lords were: What would Dr H have done if she had attended Patrick? If the court believed that she would have intubated him then the action for negligence would succeed. If she would not have intubated Patrick, then the plaintiff's action could only be successful if it was established that such an action was not 'responsible'.

The House of Lords agreed with the judge at first instance (where the case was first heard) and the majority verdict in the Court of Appeal, Per Lord Browne-Wilkinson:

'The two questions which he (the trial judge) had to decide on causation were: 1) What would Dr H have done, or authorised to be done, if she had attended Patrick? And, 2) if she would not have intubated would that have been negligent? The Bolam test has no relevance to the first of those questions but is central to the second.'

When Bolitho had been considered in the Court of Appeal, counsel for the plaintiff had argued that it was for the courts to decide the appropriate standard of care and that they should only accept the views of expert medical witnesses if they were logical. In other words advocating a move away from Bolam. The House of Lords accepted this argument to a limited extent and stated that a defendant doctor is not bound to escape liability for his actions merely on the basis of expert supporting testimony provided by his peers. Per Lord BrowneWilkinson:
'The use of these adjectives - responsible, reasonable and respectable - all show that the court has to be satisfied that the exponents of the body of medical opinion relied upon can demonstrate that such opinion has a logical basis. In particular in cases involving as they so often do, the weighing of risks against benefits, the judge before accepting a body of opinion as being responsible, reasonable or respectable will need to be satisfied that, in forming their view, the experts had directed their minds to the question of comparative risks and benefits and had reached a defensible conclusion on the matter.'

Lord Browne-Wilkinson however indicated that cases in which expert witnesses who are called to testify and assist the courts in coming to a decision will very rarely provide opinions which do not stand up to logical analysis or are unreasonable. Per Lord Browne-Wilkinson:

'It is only where a judge can be satisfied that the body of expert opinion cannot be logically supported at all that such opinion will not provide the benchmark by reference to which the defendant's conduct falls to be assessed.'

Essentially this means that expert medical witnesses must be prepared to defend their evidence and it must be seen by the courts to be reasonable and logical. This is a significant step forward from the Wednesbury unreasonable approach which was taken by Dillon LJ in the Court of Appeal where expert opinion could only be rejected on the basis that it was so unreasonable that no reasonable expert could have taken such an approach or held such a view.

The House of Lords did not abandon Bolam, but merely qualified its use. It is unlikely that their judgement will make a significant difference, as it is likely to be rare for expert medical opinion to be found to be illogical by the courts. However this decision has confirmed the courts' authority to decide between expert medical witness testimony and not only on the basis of being 'Wednesbury unreasonable.'

\section{Conclusion}

This article has looked at the development of a duty of care and the tort of negligence. 
A decision made by a High Court judge McNair J in 1957 has had a dramatic influence on medical negligence litigation by establishing the Bolam test. Apart from a limited number of cases which have usually been overturned in the appellate courts, this has made it very difficult for plaintiff patients to succeed against defendant doctors. The House of Lords decision in the Bolitho case will strengthen the courts' ability to choose between expert medical witness testimony provided the will is there. The production of clinical guidelines based on research and clinical audit could help the courts decide in the future if expert medical opinion is logical and 'main stream'.

This article is based on a dissertation which was submitted in partial fulfilment of the requirements for the degree of LLM of the University of Wales. I wish to thank Vivienne Harpwood for her supervision of this dissertation. I would also like to thank Beryl Mooney for her secretarial skills.

Donoghue v Stevenson [1932] AC 562.

2 Millner M A. Negligence in Modern Law. Butterworth, 1967.

3 Hatcher v Black. The Times, 2nd July, 1954.

4 Bolam v Friern Hospital Management Committee [1957] 2 All ER 118.

ibid.

6 Maynard $v$ West Midlands Regional Health Authority [1985] 1 All ER 635.

$7 \quad$ Whitehouse v Jordan [1981] 1 All ER 267.

8 Sidaway $v$ Bethlem Royal Hospital Governors [1985] 1 All ER 643.

9 Pearson, Royal Commission on Civil Liability and Compensation for Personal Injury 1978.

10 Edward Wong Finance Company Ltd v Johnson Stokes and Masters [1984] 1 AC 296.

11 Re: The Herald of Free Enterprise: Appeal by Captain Lewry. The Independent, 18 December 1987 D Ct.

12 Nettleship v Western [1971] 2 QB 691.

13 The Road Traffic Act 1972 first extended the notion of compulsory third party cover against death or bodily injury to include a passenger as a 'third party'. The 1988 Road Traffic Act extended that cover to a passenger's property.

14 Jones $v$ Manchester Corporation [1952] 2 All ER 125.

15 Wilsherv Essex Area Health Authority [1988] 2 WLR 557.

16 The concept of Wednesbury unreasonableness is one which is derived from the administrative law case of Associated Provincial Picture Houses Limited v Wednesbury Corporation (1948) in which it was decided the correct basis upon which the exercise of a public law power by a local authority might be challenged.

17 Hunterv Hanley [1955] SLT 213.

18 Bolam v Friern Hospital Management Committee [1957] 2 All ER 118.

19 Crawford $v$ Charing Cross Hospital The Times, 8th December 1953.

20 House of Lords Practice Statement [1966] 1 WLR 1234.

21 Bolitho $v$ City and Hackney Health Authority (1997) 39 BMLR 1; [1998] 1 Lloyds Rep Med 26.

\section{BDA Information Centre Services}

\section{Did you know?}

- As a BDA member you can gain access to one of the best dental information services in the world

- You don't have to be based in London to use the service

- You can borrow books, videos and information packages

- You can borrow up to eight items via the postal system

The only cost to you is the cost of the return postage. If you're not sure what to request then telephone us and we can advise you.

- You are entitled to free MEDLINe searches

Telephone us with a subject and we will send you a list of relevant references with abstracts.

- You can request photocopies of journal articles

There is a small charge for this service and you need to fill in a Photocopy Request Form first. Telephone us if you would like one of these forms.

\section{- You can register to receive free Current Dental Titles}

These are MEDLINE-based lists of references on eight areas of dentistry which are sent to you automatically twice a year. Phone us for a registration form.

For further details of any of these services dial $01719350875 \times 265$.

or contact us via e-mail at: Infocentre@bda-dentistry.org.uk Visit the Information Centre web pages at: www.bda-dentistry.org.uk 